\title{
Pengawasan Teknologi Finansial melalui Regulatory Sandbox oleh Bank Indonesia atau Otoritas Jasa Keuangan berdasarkan Perspektif Keadilan Bermartabat
}

\author{
Rizky P.P. Karo Karo ${ }^{1, *}$, Laurenzia Luna ${ }^{2}$ \\ ${ }^{1}$ Universitas Pelita Harapan, Jakarta, Indonesia \\ ${ }^{2}$ Universitas Pelita Harapan, Jakarta, Indonesia \\ * corresponding author
}

\section{ARTICLE INFO}

\section{Article history}

Received 2019-10-17

Revised 2019-12-02

Accepted 2019-12-18

Keywords

Regulatory Sandobox,

Financial Services Authority,

Bank Indonesia,

Dignified Justice

\begin{abstract}
Financial technology $(T F)$ cannot be released by the community both in rural areas or urban areas. TF provides a paradigm shift for the community. TF makes it easy for humans to make financial transactions simply by using a smart phone (HP) that humans can make payment transactions, borrow money. People will certainly choose TF that is safe and reliable and profitable, but sometimes people rarely know that a good and correct TF is a TF that has passed the Regulatory Sandbox (RS) test or a limited trial room. Two Government institutions that are authorized to carry out hospitals are Bank Indonesia (BI) through Bank Indonesia Regulation No: 19/12 / PBI / 2017 concerning Financial Services and Financial Services Authority (OJK) Implementation through "Financial Services Authority Regulation NUMBER 13 /POJK.02/2018 about Digital Financial Innovation in the Financial Services Sector".

The formulation of the problem raised is how is the TF supervision mechanism through the hospital implemented by BI or OJK? The method used in this scientific paper is a normative juridical method, using secondary data in the form of primary legal material consisting of laws and regulations relating to $T F$, secondary legal material in the form of scientific articles, journals and tertiary legal materials in the form of dictionaries. The research results obtained are that TF must pass the trial in the Regulatory Sandbox applied by BI or OJK. BI and OJK have the authority to determine whether the proposed TF is feasible or not feasible. RS is a significant method, according to the laws and regulations to get a TF that is suitable and safe for consumers and contains dignified justice, justice for business people and consumers.
\end{abstract}

\section{PENDAHULUAN}

Perkembangan teknologi internet, memiliki dampak negatif dan positif. Dampak negative yakni teknologi dapat disalahgunakan untuk kejahatan dan merugikan orang lain. Humans have increasingly become more dependant towards technology, including smartphones, laptops and internet. Such dependency has been due to the need to improve the quality of life by incorporative accessible technology and information within all sectors of life, such as government administration, business, banking, education. (Rizky Karo Karo, Agnes Sebastian:2019, hlm.2)

Teknologi Finanasial (selanjutnya disebut TF) tidak dapat lepas dari kehidupan manusia di era digital ini, era 4.0, baik masyarakat yang tinggal di perkotaan ataupun pedesaan, semua sudah sangat fasih menggunakan smart handphone (HP) yang dapat melakukan transaksi digital (e-commerce). TF membuat perubahan yang sangat signifikan bagi kehidupan masyarakat, jika dahulu, orang pergi ke bank untuk membuka rekening bank, sekarang hanya tinggal mendaftrar melalui aplikasi bank yang disediakan di HP.

Bank Indonesia memberikan definisi teknologi finansial bahwa "Teknologi Finansial adalah penggunaan teknologi dalam sistem keuangan yang menghasilkan produk, layanan, teknologi, dan/atau model bisnis baru serta dapat berdampak pada stabilitas moneter, stabilitas sistem keuangan, dan/atau efisiensi, kelancaran, keamanan, dan keandalan sistem pembayaran. Perkembangan teknologi finansial di satu sisi terbukti membawa manfaat bagi konsumen, pelaku usaha, maupun perekonomian nasional, namun di sisi lain memiliki potensi risiko yang apabila tidak dimitigasi secara baik dapat mengganggu sistem keuangan" (website: www.bi.go.id diakses tanggal 11 Juni 2019). 
"Otoritas Jasa Keuangan (OJK) mengklasifikasikan fintech di Indonesia ke dalam dua kategori. Fintech 2.0 untuk layanan keuangan digital yang operasikan lembaga keuangan seperti Mandiri Online besutan Bank Mandiri. Fintech 3.0 untuk startup teknologi yang punya produk dan jasa inovasi keuangan. Sedangkan, Badan internasional pemantau dan pemberi rekomendasi kebijakan mengenai sistem keuangan global, Financial Stability Board (FSB) membagi fintech dalam empat kategori berdasarkan jenis inovasi". (website: https://www.cnbcindonesia.com, artikel tanggal 10-01-2018, diakses tanggal 11 Juni 2019).

"Pertama, payment, clearing dan settlement adalah fintech yang memberikan layanan sistem pembayaran baik yang diselenggarakan oleh industri perbankan maupun yang dilakukan Bank Indonesia seperti Bank Indonesia Real Time Gross Settlement(BI-RTGS)". "Kedua, e-aggregator. Fintech ini menggumpulkan dan mengolah data yang bisa dimanfaatkan konsumen untuk membantu pengambilan keputusan. Ketiga, manajemen resiko dan investasi. Fintech ini memberikan layanan seperti robo advisor (perangkat lunak yang memberikan layanan perencanaan keuangan dan platform e-trading dan $e$ insurance. Keempat, peer to peer lending $(P 2 P)$. Fintech ini mempertemukan antara pemberi pinjaman (investor) dengan para pencari pinjaman dalam satu platform".

Berdasarkan data Asosiasi Fintech Indonesia (AFTECH), transaksi fintech dalam sub-sektor pinjammeminjam di Indonesia pada 2017 mencapai 202,77 trilliun dollar AS, meningkat 24,6 persen dari tahun 2016. (website: https://ekonomi.kompas.com, artikel tanggal 18-10-2018, diakses tanggal 11 Juni 2019). Menurut pencatatan dan survey Asosiasi Financial Technology Indonesia (Aftech bahwa angka TF di Indonesia sangat pesat yakni Menurut survei tersebut hingga 2018 jumlah anggota Aftech mencapai 178 start-up. Jumlah itu meningkat drastis sejak Aftech dibentuk pada 2016 yang pada awalnya berjumlah 6 anggota. Total investasi sektor fintech di Indonesia pun dicatat meningkat 93\% dibandingkan 2017 (website: https://finance.detik.com/ artikel tanggal 2-5-2019, diakses tanggal 11 Juni 2019).

Peer to peer lending memberikan efek pendapatan bagi negara. "Menurut Direktur Pengaturan, Perizinan dan Pengawasan Financial Technology OJK Hendrikus Passagi bahwa peer to peer lending menyalurka dana Rp. 25 triliun dan memberikan efek positif bagi peningkatan lapangan pekerjaan hingga 250.000 orang". "Menurut Hendrikus, Sekarang ini ada sekitar 3 juta penduduk di seluruh Indonesia yang menggunakan fintech peer to peer lending dan ada sekitar 9 juta transaksi". (website: https://finance.detik.com/ artikel tanggal 12-10-2018, diakses tanggal 11 Juni 2019).

TF yang telah beroperasi di Indonesia adalah TF yang telah lulus uji regulatory sandbox (RS). "Konsep regulatory sandbox sebagai proses seleksi sebuah konsep fintech dimulai dari Inggris Raya dan selanjutnya diikuti oleh negara-negara lain yang memiliki kemajuan fintech seperti Amerika Serikat (AS), Australia, Cina, dan juga Singapura. Prinsip dasar regulatory sandbox di seluruh dunia memiliki tujuan yang sama yaitu proses pembelajaran dan uji coba. Tujuan berikutnya adalah memberikan waktu bagi inovator untuk melakukan pembenahan maupun memperbaiki tata kelola maupun risiko bisnis" (website: https://tirto.id/, artikel tanggal 26-04-2018, diakses tanggal 11 Juni 2019).

Karya ilmiah ini juga adalah hasil kajian lebih lanjut yang diperoleh dari Laporan Penelitian LPPM UPH dengan no. 441 / LPPM - UPH / XII / 2018 yang diketuai oleh Prof. Dr. Teguh Prasetyo, S.H., M.Si. dan beranggotakan: 1. Rizky Karo Karo (Dosen FH UPH) dan 2. Vena Pricilia (Mahasiswi FH UPH) dengan judul "urgensi pembentukan peraturan hukum tentang pemanfaatan teknologi blockchain di Indonesia ". Bahwasanya blockchain termasuk dalam IKD dalam kategori aktivitas jasa keuangan lainnya. Pemanfaatan blockchain akan merubah paradgima sistem pembayaran perbankan di Indonesia oleh karenanya sistem teknologi blockchain wajib diawasi oleh OJK, BI, Pusat Pelaporan dan Analisis Transaksi Keuangan (PPATK) dan instansi Pemerintah lainnya yang berwenang mengingat sistem blockchain ini memiliki keamanan data yang sulit dibobol dan sangat privasi sehingga memiliki potensi untuk disalahgunakan secara melawan hukum.

Otoritas Jasa Keuangan (OJK) dan Bank Indonesia (BI) adalah 2 (dua) otoritas Pemerintah yang memiliki wewenang untuk menjalankan $R S$. Oleh karena itu, Penulis mengambil rumusan masalah: 1 . Bagaimana pengawasan teknologi finansial melalui regulatory sandbox oleh Otoritas Jasa Keuangan berdasarkan perspektif keadilan bermartabat? 2. Bagaimana pengawasan teknologi finansial melalui regulatory sandbox oleh Bank Indonesia berdasarkan perspektif keadilan bermartabat? 


\section{METODE PENELITIAN}

Metode penelitian dan penulisan yang Penulis gunakan adalah metode yuridis normatif. Penulisan ini dilakukan dengan menggunakan penulisan yuridis normatif. "Jenis penulisan yuridis normatif adalah penulisan yang dilakukan dengan meneliti bahan pustaka atau data sekunder. Pendekatan yuridis normative dilakukan dengan cara menelaah teori-teori, konsep dan peraturan perundang-undangan yang ada dan berhubungan dengan masalah yang penulis bahas" (Soerjono Soekanto, 2004, hal.11). Pendekatan yang penulis gunakan adalah pendekatan undang-undang (legal approach) yakni dilakukan dengan menelaah semua undang-undang dan regulasi yang berkaitan dengan isu hukum (Sri Mamudji, et al, 2005, hal.93).

Penulisan ini menggunakan data sekunder yang berupa bahan hukum primer, bahan hukum sekunder dan bahan hukum tersier. Bahan hukum primer terdiri dari: “a. Undang-undang Dasar Negara Republik Indonesia (UUD 1945), b. Undang-undang No. 23 Tahun 2009 tentang Bank Indonesia sebagaimana telah beberapa kali diubah, terakhir dengan Undang-undang Nomor 6 Tahun 2009; c. Undang-undang Nomor 21 Tahun 2011 tentang Otoritas Jasa Keuangan"; d. Peraturan Perundang-undangan lainnya yang berkaitan dengan topic penulis. Adapun bahan hukum sekunder yang penulis gunakan berupa laporan penelitian tentang topik yang sejenis, artikel ilmiah, jurnal dan publikasi lainnya, sedangkan bahan hukum tersier yang penulis gunakan ialah berupa kamus hukum. Analisis data yang penulis gunakan adalah dilakukan secara analisis kualitatif. Analisis kualitatif adalah kegiatan menganalisis melalui cara berpikir formal dan argumentatif (M.Syamsudin, 2007, hal.133). Penulis menggunakan metode deduktif untuk mengambil kesimpulan berdasarkan data-data dan pembahasan.

\section{HASIL DAN PEMBAHASAN}

\section{Pengawasan Teknologi Finansial Melalui Regulatory Sandbox oleh Bank Indonesia Berdasarkan Perspektif Keadilan Bermartabat}

\section{Keadilan Bermartabat}

Keadilan bermartabat adalah konsep yang digagas oleh Prof. Teguh Prasetyo, "Teori Keadilan Bermartabat tidak anti terhadap teori-teori yang selama ini ada dan dirujuk dalam menjelaskan hukum yang berlaku di Indonesia. Namun Keadilan Bermartabat berusaha memberi teladan untuk ber-hukum, termasuk mencaridan membangun atau melakukan konstruksi maupun rekonstruksi atas hukum serta penjelasan tentang hukum itu dari falsafah atau filosofis yang digali dari dalam bumi Indonesia sendiri; tidak harus bergantung kepada teori-teori, konsep-konsep yang dikembangkan di dalam sistem hukum yang lain".

"Dalam perspektif Teori Keadilan Bermartabat, atau Keadilan Bermartabat, keadilan itu adalah tempat berhimpunnya tiga tujuan hukum yang dikemukakan oleh Gustav Radbruch" (keadilan, kepastian dan kemanfaatan) (Teguh Prasetyo, 2015, hlm.112-113).

Menurut hemat Penulis, $R S$ yang diatur dan diwajibkan oleh otoritas yang berwenang baik OJK ataupun BI adalah prinsip untuk melindungi konsumen dari tindakan melawan hukum pelaku usaha Tekfin dan pelaku usaha juga mendapatkan kepastian hukum dalam menjalankan usaha teknologi finansial di Indonesia.

\section{Kewenangan Bank Indonesia}

Bank Indonesia adalah bank sentral Republik Indonesia. Berdasarkan Pasal 4 ayat (2) UU Bank Indonesia bahwa "Bank Indonesia adalah lembaga negara yang independen, bebas dari campur tangan Pemerintah dan/atau pihak-pihak lainnya, kecuali untuk hal-hal yang secara tegas diatur dalam undangundang ini". BI memiliki tujuan untuk "mencapai dan memelihara kestabilan nilai rupiah. Berdasarkan Pasal 8 UU BI bahwa BI memiliki tugas yang mulia ialah: a. menetapkan dan melaksanakan kebijakan moneter; b. mengatur dan menjaga kelancaran sistem pembayaran; c. mengatur dan mengawasi Bank".

Kewenangan BI dalam rangka mengatur dan menjaga lekancaran sistem pembayaran ialah: "a. melaksanakan dan memberikan persetujuan dan izin atas penyelenggaraan jasa sistem pembayaran; $b$. mewajibkan penyelenggara jasa sistem pembayaran untuk menyampaikan laporan tentang kegiatannya; $\mathrm{c}$. menetapkan penggunaan alat pembayaran" [Pasal 15 ayat (1) UU BI].

"BI menetapakan peraturan, memberikan dan mencabut izin atas kelembagaan dan kegiatan usaha tertentu dari Bank, melaksanakan pengawasan Bank, dan mengenakan sanksi terhadap Bank sesuai dengan ketentuan perundang-undangan" (Pasal 24 UU BI). 
Kewenangan BI di bidang perizinan ialah: "a. memberikan dan mencabut izin usaha Bank; b. memberikan izin pembukaan, penutupan, dan pemindahan kantor Bank; c. memberikan persetujuan atas kepemilikan dan kepengurusan Bank; d. memberikan izin kepada Bank untuk menjalankan kegiatan-kegiatan usaha tertentu" (Pasal 26 UU BI).

\section{Peraturan BI tentang Penyelenggaraan Teknologi Finanasial}

PADG 19/14/PADG/2017 tentang Ruang Uji Coba Terbatas / Regulatory Sandbox. BI telah mengeluarkan Peraturan Bank Indonesia No. 19 / 12 / PBI / 2017 tentang penyelenggaran teknologi finansial (PBI PTF) agar penyelenggaraan teknologi finansial berjalan dengan semestinya. "Bank Indonesia mengatur penyelenggaraan Teknologi Finansial untuk mendorong inovasi di bidang keuangan dengan menerapkan prinsip perlindungan konsumen serta manajemen risiko dan kehati-hatian guna tetap menjaga stabilitas moneter, stabilitas sistem keuangan, dan sistem pembayaran yang efisien, lancar, aman, dan andal" (Pasal 2 PBI PTF).

BI mengkategorikan penyelenggaraan teknologi finanasial yakni: a. sistem pembayaran; b. pendukung pasar; c. manajemen investasi dan manajemen risiko; d. pinjaman, pembiayaan, dan penyediaan modal; dan e. jasa finansial lainnya. [Pasal 3 ayat (1) PBI PTF]. TF tersebut harus memiliki kriteria yakni: "a. bersifat inovatif; b. dapat berdampak pada produk, layanan, teknologi, dan/atau model bisnis finansial yang telah eksis; c. dapat memberikan manfaat bagi masyarakat; d. dapat digunakan secara luas; dan e. kriteria lain yang ditetapkan oleh Bank Indonesia" [Pasal 3 ayat (2) PBI PTF].

BI memiliki kewenangan untuk menetapkan apakah suatu Penyelenggara Teknologi Finansial dapat dilakukan uji coba / regulatory sandbox. Penetapan tersebut dengan mempertimbangkan aspek sebagai berikut: "a. Penyelenggara Teknologi Finansial telah terdaftar di Bank Indonesia; b. Teknologi Finansial yang diselenggarakan mengandung unsur yang dapat dikategorikan ke dalam sistem pembayaran; c. Teknologi Finansial mengandung unsur Inovasi; d. Teknologi Finansial bermanfaat atau dapat memberi manfaat bagi konsumen dan/atau perekonomian; e. Teknologi Finansial bersifat noneksklusif; f. Teknologi Finansial dapat digunakan secara massal; g. Teknologi Finansial telah dilengkapi dengan identifikasi dan mitigasi risiko; dan h. hal lain yang dianggap penting oleh Bank Indonesia" [ Pasal 3 ayat (2) Peraturan Anggota Dewan Gubernur No 19

\section{Regulatory Sandbox oleh Bank Indonesia}

Definisi yuridis regulatory sandbox (RS) sebagaimana diatur dalam Pasal 1 angka 4 PBI PTF adalah "suatu ruang uji coba terbatas yang aman untuk menguji Penyelenggara Teknologi Finansial beserta produk, layanan, teknologi, dan/atau model bisnisnya". Menurut hemat Penulis, RS ditujukan untuk mendapatkan penyelenggara TF yang baik, taat hukum, dapat memanjemen risiko, dan aman bagi konsumen. Oleh karena itu, Bank Indonesia menyelenggaraan RS. BI memiliki kewenangan untuk "menetapkan Penyelenggara Teknologi Finansial beserta produk, layanan, teknologi, dan/atau model bisnisnya untuk diuji coba dalam Regulatory Sandbox".

Penyelenggara TF yang dapat diuji coba dalam RS wajib telah terdaftar oleh BI sesuai ketentuan Pasal 7 PBI PTF. Berdasarkan Pasal 12 ayat (1) PBI PTF bahwa Bank Indonesia menetapkan jangka waktu tertentu bagi Penyelenggara Teknologi Finansial untuk melakukan uji coba dalam Regulatory Sandbox.

Berdasarkan Pasal 12 ayat (2) PBI PTF bahwa "Setelah jangka waktu sebagaimana dimaksud pada ayat (1) berakhir, Bank Indonesia menetapkan status hasil uji coba Penyelenggara Teknologi Finansial berupa: a. berhasil; b. tidak berhasil; atau c. status lain yang ditetapkan Bank Indonesia".

Jika dinyatakan berhasil, "produk, layanan, teknologi, dan/atau model bisnisnya termasuk Teknologi Finansial kategori sistem pembayaran maka Penyelenggara Teknologi Finansial dilarang memasarkan produk, layanan, teknologi, dan/atau model bisnis yang diujicobakan sebelum terlebih dahulu mengajukan permohonan izin dan/atau persetujuan sesuai dengan ketentuan Bank Indonesia yang mengatur mengenai penyelenggaraan pemrosesan transaksi pembayaran" [Pasal 12 ayat (3) PBI 2017]. Jika uji coba dinyatakan tidak berhasil maka "produk, layanan, teknologi, dan/atau model bisnisnya termasuk Teknologi Finansial kategori sistem pembayaran maka Penyelenggara Teknologi Finansial dilarang memasarkan produk dan/atau layanan serta menggunakan teknologi dan/atau model bisnis yang diujicobakan" [Pasal 12 ayat (4) PBI 2017].

Berdasarkan Pasal 13 ayat (1) PBI PTF, Selama proses uji coba dalam Regulatory Sandbox, Bank Indonesia dapat menetapkan kebijakan tertentu bagi Penyelenggara Teknologi Finansial. Menurut hemat 
Penulis, berdasarkan perspektif keadilan bermartbat bahwa, kebijakan tertentu tersebut tidak boleh merusak sistem TF namun harus memperhatikan karakteristik produk, layanan, teknologi yang digunakan.

\section{Sanksi oleh Bank Indonesia}

Bank Indonesia memiliki kewenangan untuk menjatuhkan sanksi administratf bagi pelaku usaha yang melanggar PBI PTF. Sanksi administrative berupa: "a. teguran tertulis; dan/atau b. penghapusan dari daftar penyelenggara Teknologi Finanasial di Bank Indonesia dapat diberikan jika PTF melanggar Pasal 8 ayat (1), Pasal 8 ayat (2), Pasal 8 ayat (3), Pasal 12 ayat (3), Pasal 12 ayat (4), dan/atau Pasal 16 ayat (2).

Menurut hemat Penulis, sanksi yang diberikan ini adalah sesuai dengan prinsip keadilan bermartabat bahwasanya penyelenggara TF yang tidak lolos uji RS maka tidak layak untuk memasarkan teknologinya kepada masyarakat karena berbahaya bagi nasabah/konsumen. Tindakan tersebut adalah langkah pencegahan yang sangat tepat.

\section{Pengawasan Teknologi Finansial Melalui Regulatory Sandbox oleh Otoritas Jasa Keuangan Berdasarkan Perspektif Keadilan Bermartabat}

\section{Kewenangan OJK}

Payung hukum yang mengatur tentang Otoritas Jasa Keuangan (OJK) adalah Undang-undang Nomor 21 Tahun 2011 (UU OJK). Otoritas Jasa Keuangan (OJK) adalah "lembaga yang independen dan bebas dari campur tangan pihak lain, yang mempunyai fungsi, tugas, dan wewenang pengaturan, pengawasan, pemeriksaan, dan penyidikan sebagaimana dimaksud dalam UndangUndang ini. Berdasarkan Pasal 4 UU OJK bahwa OJK dibentuk dengan tujuan agar keseluruhan kegiatan di dalam sektor jasa keuangan: a. terselenggara secara teratur, adil, transparan, dan akuntabel; b. mampu mewujudkan sistem keuangan yang tumbuh secara berkelanjutan dan stabil; dan c. mampu melindungi kepentingan Konsumen dan masyarakat".

Berdasarkan Pasal 6 UU OJK bahwa OJK melaksanakan tugas pengaturan dan pengawasan terhadap: "a. kegiatan jasa keuangan di sektor Perbankan; b. kegiatan jasa keuangan di sektor Pasar Modal; dan c. kegiatan jasa keuangan di sektor Perasuransian, Dana Pensiun, Lembaga Pembiayaan, dan Lembaga Jasa Keuangan Lainnya". Berdasarkan Pasal 1 angka 10 UU OJK, yang dimaksud dengan "Lembaga Jasa Keuangan Lainnya adalah pegadaian, lembaga penjaminan, lembaga pembiayaan ekspor Indonesia, perusahaan pembiayaan sekunder perumahan, dan lembaga yang menyelenggarakan pengelolaan dana masyarakat yang bersifat wajib, meliputi penyelenggara program jaminan sosial, pensiun, dan kesejahteraan, sebagaimana dimaksud dalam peraturan perundang-undangan mengenai pergadaian, penjaminan, lembaga pembiayaan ekspor Indonesia, perusahaan pembiayaan sekunder perumahan, dan pengelolaan dana masyarakat yang bersifat wajib, serta lembaga jasa keuangan lain yang dinyatakan diawasi oleh OJK berdasarkan peraturan perundang-undangan".

OJK memiliki pelbagai wewenang untuk mengatur dan mengawasi lembaga keuangan. Penulis sarikan kewenagan OJK yang berkaitan dengan teknologi finansial (TF) berdasarkan UU OJK, yakni:

1. menetapkan peraturan dan keputusan OJK (Pasal 8 huruf c);

2. menetapkan peraturan mengenai pengawasan di sektor jasa keuangan (Pasal 8 huruf d);

3. menetapkan peraturan mengenai tata cara pengenaan sanksi sesuai dengan ketentuan peraturan perundangundangan di sektor jasa keuangan (Pasal 8 huruf i);

4. menetapkan kebijakan operasional pengawasan terhadap kegiatan jasa keuangan (Pasal 9 huruf a);

5. menetapkan sanksi administratif terhadap pihak yang melakukan pelanggaran terhadap peraturan perundangundangan di sektor jasa keuangan (Pasal 8 huruf g);

6. "memberikan dan/atau mencabut: a. izin usaha; b. izin orang perseorangan; c. efektifnya pernyataan pendaftaran; d. surat tanda terdaftar; e. persetujuan melakukan kegiatan usaha; f. pengesahan; g. persetujuan atau penetapan pembubaran; dan h. penetapan lain",

\section{Regulatory Sandbox}

OJK telah menerbitkan Peraturan OJK yang mengatur tentang tata cara $R S$ yakni pada: Peraturan Otorias Jasa Keuangan No 13/POJK.02/2018 tentang Invoasi Keuangan Digital di Sektor Jasa Keuangan (selanjutnya disebut POJK IKD).

Berdasarkan Pasal 1 angka 4 POJK IKD, RS adalah "mekanisme pengujian yang dilakukan oleh Otoritas Jasa Keuangan untuk menilai keandalan proses bisnis, model bisnis, instrumen keuangan, dan tata kelola Penyelenggara”. Sedangkan definsi Inovasi Keuangan Digital sebagaimana dalam Pasal 1 angka 1 
POJK IKD ialah "aktivitas pembaruan proses bisnis, model bisnis, dan instrumen keuangan yang memberikan nilai tambah baru di sektor jasa keuangan dengan melibatkan ekosistem digital".

Berdasarkan Pasal 3 POJK IKD, ruang lingkup IKD meliputi: a. penyelesaian transaksi; b. penghimpun modal; c. pengelolaan investasi; d. penghimpunan dan penyaluran dana; e. perasuransian; $f$. pendukung pasar; g. pendukung keuangan digital lainnya; dan/atau h. aktivitas jasa keuangan lainnya.

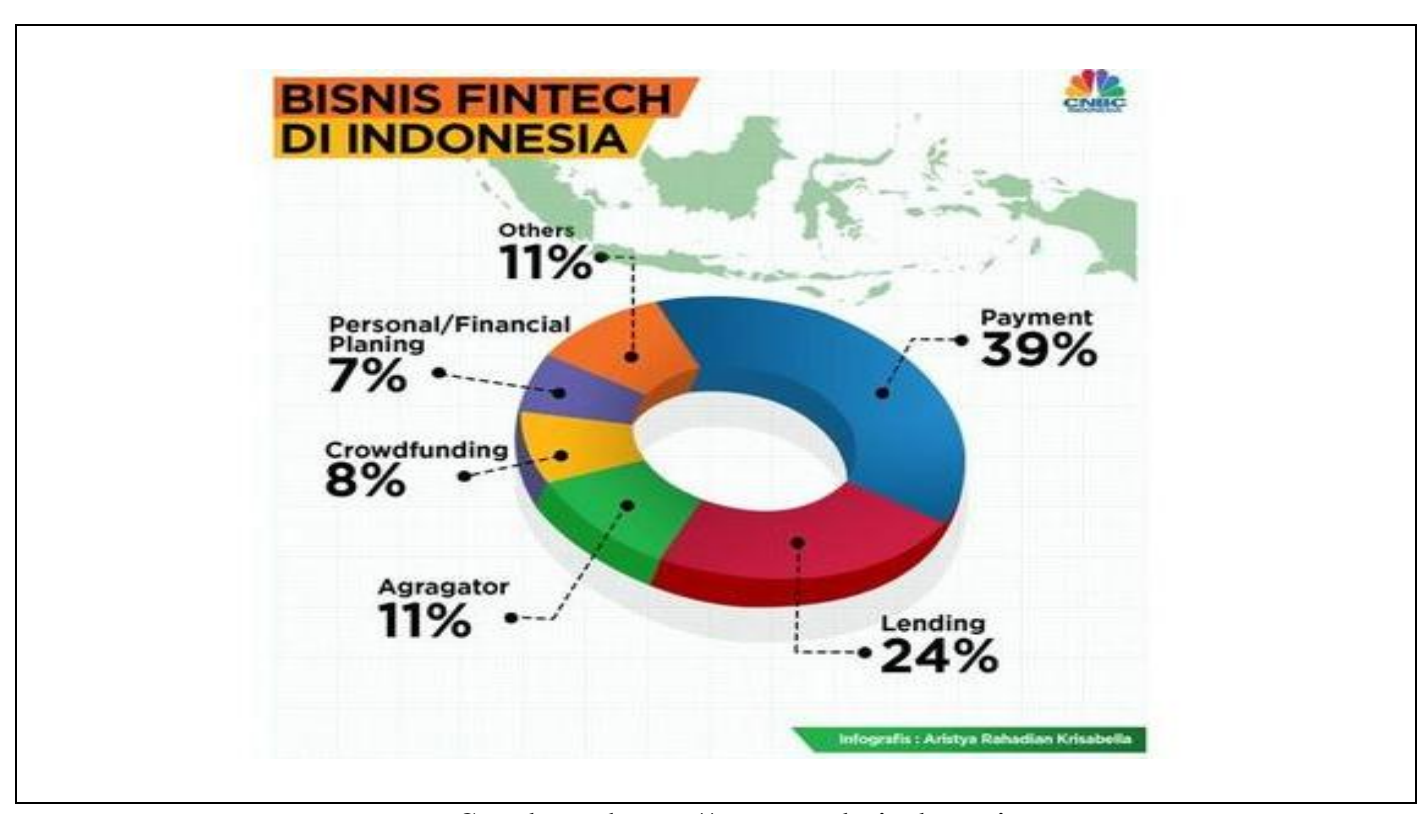

Sumber : https://www.cnbcindonesia.com

Gambar 1. Pengawasan oleh OJK melalui Regulatory Sandbox

Survei CNBC diatas dapat ditarik kesimpulan bahwa TF telah banyak digunakan oleh masyarakat Indonesia. Menurut hemat Penulis, TF sangat memudahkan kehidupan masyarakat dalam bertransaksi daring, online.

Pertama, OJK akan melakukan pencatatan terhadap perusahaan yang ingin diuji coba melalui RS maka wajib melakukan permohonan pencatatan.

"Otoritas Jasa Keuangan melakukan pencatatan atas permohonan pencatatan yang diajukan oleh Penyelenggara dengan mempertimbangkan kelengkapan dokumen yang disampaikan oleh Penyelenggara meliputi”: a. salinan akta pendirian badan hukum Penyelenggara beserta identitas kelengkapan data pengurus; b. penjelasan singkat secara tertulis mengenai produk; c. data dan informasi lainnya yang terkait dengan kegiatan IKD; dan d. rencana bisnis.

Otoritas Jasa Keuangan (OJK ) pada 15 Mei 2019 telah menerbitkan izin 4 perusahaan financial technology (fintech) lending. Dengan keluarnya 4 izin ini, maka ada 5 perusahaan yang sudah mengantongi izin dan 108 perusahaan lainnya masih berstatus terdaftar. Beberapa contohnya ialah: Investree, Dompet Kilat, Amartha, dan KIMO. (https://finance.detik.com/ artikel tanggal 16-05-2019, diakses tanggal 11 Juni 2019).

Menurut hemat Penulis, izin yang diberikan oleh OJK membuat pelaku usaha memiliki tanggung jawab lebih kepada konsumen, dan tanggung jawab untuk mengelola risiko yang lebih baik.

"Menurut CEO Investree Adrian Gunadi untuk mendapatkan izin tersebut Investree membutuhkan waktu selama 2 tahun. Dalam proses izin tersebut Investree melakukan live visit hingga live demo. Sekarang sudah berstatus izin maka ada risk management yang harus ditambah karena bagaimanapun ini adalah lembaga jasa keuangan "(https://finance.detik.com/ artikel tanggal 16-05-2019, diakses tanggal 11 Juni 2019).

Menurut hemat Penulis, TF termasuk dalam IKD, berdasarkan Pasal 4 POJK IKD, kriteria IKD yakni: "a. bersifat inovatif dan berorientasi ke depan; b. menggunakan teknologi informasi dan komunikasi sebagai sarana utama pemberian layanan kepada konsumen di sektor jasa keuangan; c. mendukung inklusi dan 
literasi keuangan; d. bermanfaat dan dapat dipergunakan secara luas; e. dapat diintegrasikan pada layanan keuangan yang telah ada; f. menggunakan pendekatan kolaboratif; dan g. memperhatikan aspek perlindungan konsumen dan perlindungan data".

Otoritas Jasa Keuangan menyelenggarakan Regulatory Sandbox untuk memastikan IKD memenuhi kriteria sebagaimana dimaksud dalam Pasal 4. Berdasarkan Pasal 8 ayat (1) POJK IKD bahwa "Otoritas Jasa Keuangan menetapkan Penyelenggara untuk diuji coba dalam Regulatory Sandbox. Penyelenggara IKD terdiri dari: a. lembaga jasa keuangan, dan b. pihak lain yang melakukan kegiatan di sektor jasa keuangan”.

Berdasarkan Pasal 8 ayat (2) POJK IKD, penetapan penyelenggara yang dapat diuji coba melalui regulatory sandbox ialah: "a. tercatat sebagai IKD di Otoritas Jasa Keuangan atau berdasarkan surat permohonan yang diajukan satuan kerja pengawas terkait di Otoritas Jasa Keuangan; b. merupakan bisnis model yang baru; c. memiliki skala usaha dengan cakupan pasar yang luas; d. terdaftar di asosiasi Penyelenggara; dan e. kriteria lain yang ditetapkan oleh Otoritas Jasa Keuangan”.

Jika pada $R S$ ditemukan bahwa TF memiliki kewenangan dengan otortias lain, OJK akan berkoordinasi dengan otoritas tersebut, namun tetap di bawah koordinasi OJK. Pada saat pelaksanaan $R F$, OJK dapat meminta informasi tambahan yang diperlukan.

OJK "berwenang melakukan pemantauan terhadap Penyelenggara yang telah tercatat dan terdaftar di Otoritas Jasa Keuangan" [Pasal 17 ayat (1) POJK IKD] dan "untuk melengkapi mekanisme pemantauan oleh Otoritas Jasa Keuangan, Penyelenggara diwajibkan untuk menerapkan prinsip pemantauan secara mandiri (self-assessment)".

"Prinsip pemantauan secara mandiri paling sedikit meliputi: a. prinsip tata kelola teknologi informasi dan komunikasi sesuai dengan peraturan perundangundangan; b. perlindungan konsumen sesuai dengan ketentuan Peraturan Otoritas Jasa Keuangan ini; c. edukasi dan sosialisasi kepada konsumen; d. kerahasiaan data dan/atau informasi konsumen termasuk data dan/atau informasi transaksi; e. prinsip manajemen risiko dan kehati-hatian; f. prinsip anti pencucian uang dan pencegahan pendanaan terorisme sesuai dengan ketentuan peraturan perundang-undangan; dan g. inklusif dan prinsip keterbukaan informasi" [Pasal 18 ayat (1) POJK IKD].

OJK melarang penyelenggara TF "untuk memberikan data dan/atau informasi mengenai konsumen kepada pihak ketiga" [Pasal 38 ayat (1) POJK IKD] baik berupa data pribadi, data keuangan. Namun, berdasarkan Pasal 38 ayat (2) POJK IKD. "Larangan sebagaimana dimaksud pada ayat (1) dikecualikan dalam hal: a. konsumen memberikan persetujuan secara elektronik; dan/atau b. Penyelenggara diwajibkan oleh ketentuan peraturan perundang-undangan untuk memberikan data dan/atau informasi mengenai konsumen kepada pihak ketiga".

Menurut hemat Penulis, larangan tersebut sudah tepat dan telah sesuai prinsip keadilan bermartabat. Bahwasanya saat ini, Indonesia belum memiliki UU Perlindungan Data Pribadi sehingga larangan tersebut memberikan perlindungan hukum bagi nasabah dan mencegah pelaku usaha untuk memanfaatkan data pribadi pengguna secara tidak berhak.

Pengguna TF memiliki hak atas kerhasiaan data pribadinya, mendapatkan akses untuk memperbaharui data pribadinya. Dan jika dimanfaatkan secara tidak berhak, maka pelaku usaha, penyelenggara TF dapat diancam dengan UU ITE Pasal 26 ataupun Pasal 378 tentang Penipuan (Rizky Karo Karo, 2019, hlm.157).

\section{Penyelenggaraan Regulatory Sandbox}

"Regulatory Sandbox dilaksanakan dalam jangka waktu paling lama 1 (satu) tahun dan dapat diperpanjang selama 6 (enam) bulan apabila diperlukan (Pasal 9 POJK IKD)". "Selama pelaksanaan Regulatory Sandbox, Penyelenggara wajib memenuhi ketentuan sebagai berikut: a. memberitahukan setiap perubahan IKD yang dimiliki; b. berkomitmen untuk membuka setiap informasi yang berkaitan dengan pelaksanaan Regulatory Sandbox; c. mengikuti edukasi dan konseling yang diperlukan untuk pengembangan bisnis sektor jasa keuangan; d. mengikuti setiap pelaksanaan koordinasi dan kerja sama dengan otoritas atau kementerian/lembaga lain; dan e. berkolaborasi dengan Lembaga Jasa Keuangan atau pihak yang melakukan kegiatan di sektor jasa keuangan" (Pasal 10 POJK IKD).

Jika telah diuji coba maka, OJK dapat menyatakan status: "a. direkomendasikan, b. perbaikan, c. tidak direkomendasikan". Jika bersatus direkomendasikan maka Otoritas Jasa Keuangan akan memberikan rekomendasi pendaftaran sesuai dengan aktivitas usaha dari Penyelenggara (Pasal 11 ayat 2 POJK IKD). 
"Jika dalam satus perbaikan, Otoritas Jasa Keuangan dapat memberikan perpanjangan waktu dengan jangka waktu paling lama 6 (enam) bulan sejak tanggal penetapan status (Pasal 11 ayat 3 POJK IKD)".

Jika penyelenggara dalam hal hasil uji coba berstatus tidak direkomendasikan, penyelenggara tidak dapat mengajukan kembali IKD yang sama (Pasal 11 ayat 4 POJK IKD) dan dikeluarkan dari pencatatan sebagai penyelenggara (Pasal 11 ayat 5 POJK IKD). "Penyelenggara yang sedang dalam proses Regulatory Sandbox wajib menyampaikan laporan kinerja berkala secara triwulanan kepada Otoritas Jasa Keuangan".

\section{Sanksi yang diberikan oleh OJK}

Jika pelaku usaha, penyelenggara TF tetap nekat menjalankan usahanya tanpa izin dari OJK maka hal tersebut telah termasuk kejahatan dunia maya. Kejahatan yang menggunakan sarana komputer/HP dan internet dan menyerang sistem elektronik, harkat martabat manusia, data pribadi dan harta materiil/imateriil seseorang ataupun badan hukum (Rizky Karo Karo, 2019, hlm.46).

Technology development drives humans to follow the current trend of the modern internet and technology era. The misuse of technology and internet leads to cybercrime. Prior to the enactment of UU ITE, crimes within the cyberspace are prosecuted on the basis of Indonesian Criminal Code as it provides a foundational and broader scope of crime. Thus, referring to traditional mea ns of fraud, such crime is punishable based on article 378 of Indonesian Criminal Code (Rizky Karo Karo, Agnes Sebastian, 2019, hlm.5). Jika konsumen ingin mengadu/melapor baik karena pencurian data pribadi, pengancaman yang dilakukan dengan media elektronik maka wajib melampirkan bukti elektronik (screenshots) yang adalah bukti yang sah berdasarkan UU ITE (Rizky Karo Karo, Kolom Pendapat, Koran Tempo 18 Juni 2019).

Berdasarkan Pasal 39 ayat (1) UU OJK bahwa "Otoritas Jasa Keuangan berwenang mengenakan sanksi administratif terhadap setiap pihak yang melakukan pelanggaran ketentuan Peraturan Otoritas Jasa Keuangan ini, termasuk pihak yang menyebabkan terjadinya pelanggaran tersebut berupa: a. peringatan tertulis; b. denda, yaitu kewajiban untuk membayar sejumlah uang tertentu; c. pembatalan persetujuan; dan/atau d. pembatalan pendaftaran".

Selain hukuman berupa hukuman yang bersifat administrasi, "Otoritas Jasa Keuangan dapat melakukan tindakan tertentu terhadap setiap pihak yang melakukan pelanggaran ketentuan Peraturan Otoritas Jasa Keuangan ini” (Pasal 40 POJK IKD). Namun, POJK IKD tidak menjelaskan lebih lanjut dalam POJK IKD. Oleh karena itu, menurut hemat Penulis, berdasarkan prinsip keadilan bermartabat bahwa tindakan yang diberikan oleh OJK adalah tindakan yang win-win solution dan agar penyelenggara $\mathrm{TF}$ segera memperbaharui izin atau dokumen yang diperlukan.

\section{KESIMPULAN}

Berdasarkan pembahasan diatas, maka Penulis mengambil kesimpulan bahwa:

Otoritas Jasa Keuangan (OJK) dan Bank Indonesia (BI) memiliki kewenangan secara hukum untuk melaksanakan uji coba terhadap TF melalui Regulatory Sandbox. Uji coba melalui $R S$ diberikan bagi pelaku usaha, penyelenggara TF yang telah didaftarkan dalam sistem BI atau OJK dan bagi penyelenggara TF yang telah lolos penetapan oleh BI ataupun OJK. Tujuan $R S$ ini jelas untuk memberikan perlindungan bagi konsumen, bagi calon pengguna, memberikan kepastian hukum bagi penyelenggara TF agar dapat menjalankan usahanya sesuai peraturan perundang-undangan yang berlaku dan sesuai dengan perspektif keadilan bermartabat. $R S$ adalah bentuk pengawasan nyata dan sah secara hukum oleh OJK ataupun BI terhadap penyelenggaraan TF dan telah berisikan prinsip keadilan bermartabat.

BI memiliki wewenang untuk melakukan $R S$ dan mengawasi TF yang memiliki fungsi sebagai sistem pembayaran agar lebih efisien sedangkan OJK memiliki wewenang untuk melakukan $R S$ dan untuk mengawasi TF yang memiliki fungsi diluar sistem pembayaran.

\section{DAFTAR PUSTAKA}

\section{Buku}

Karo Karo, Rizky , (2019). Penegakan Hukum Kejahatan Dunia Maya (Cybercrime) Melalui Hukum Pidana, Karawaci: Penerbit Fakultas Hukum, Universitas Pelita Harapan. 
Mamudji,Sri, et.al., (2005). Metode Penelitian dan Penelitian Hukum. Jakarta: Badan Penerbit Fakultas Hukum Universitas Indonesia.

Syamsudin, M.(2007). Operasionalisasi Penelitian Hukum. Jakarta: PT Raja Grafindo Persada.

Soekanto, Soerjono. (2004). Penelitian Hukum Normatif. Jakarta: PT. Raja Grafindo Persada.

Teguh Prasetyo, Teguh. (2015). Keadilan Bermartabat Perspektif Teori Hukum. Bandung: Nusa Media.

\section{Jurnal}

Karo Karo, Rizky \& Sebastian Agnes. (2019). Juridical Analysis on the Criminal Act of Online Shop Fraud in Indonesia. Lentera Hukum, Vol 6 Issue 1 (2019), p.1-14, ISSN P: 2355-4673, ISSN-E: 2621-3710, doi: https://doi.org/10.19184/ejlh.v6i1.9567

\section{Artikel}

Rizky Karo Karo, “Bukti Elektronik Sudah Final”, Koran Tempo tanggal 18 Juni 2019

\section{Laporan Penelitian}

Penelitian Dana Internal dengan no. 441 / LPPM - UPH / XII / 2018 yang diketuai oleh Prof. Dr. Teguh Prasetyo, S.H., M.Si dan beranggotakan: Rizky Karo Karo (dosen) dan Vena Pricilia (Mahasiswi) dengan judul "Urgensi Pembentukan Peraturan Hukum Tentang Pemanfaatan Teknologi Blockchain Di Indonesia".

\section{Peraturan Perundang-undangan}

Undang-undang Dasar Negara Republik Indonesia Tahun 1045

Undang-Undang Nomor 23 Tahun 1999 tentang Bank Indonesia (Lembaran Negara Republik Indonesia Tahun 1999 Nomor 66, Tambahan Lembaran Negara Republik Indonesia Nomor 3843) sebagaimana telah beberapa kali diubah, terakhir dengan Undang-Undang Nomor 6 Tahun 2009 tentang Penetapan Peraturan Pemerintah Pengganti Undang-Undang Nomor 2 Tahun 2008 tentang Perubahan Kedua atas Undang-Undang Nomor 23 Tahun 1999 tentang Bank Indonesia menjadi Undang-Undang (Lembaran Negara Republik Indonesia Tahun 2009 Nomor 7, Tambahan Lembaran Negara Republik Indonesia Nomor 4962);

Undang-Undang Nomor 11 Tahun 2008 tentang Informasi dan Transaksi Elektronik (Lembaran Negara Republik Indonesia Tahun 2008 Nomor 58, Tambahan Lembaran Negara Republik Indonesia Nomor 4843) sebagaimana telah diubah dengan Undang-Undang Nomor 19 Tahun 2016 tentang Perubahan atas Undang-Undang Nomor 11 Tahun 2008 tentang Informasi dan Transaksi Elektronik (Lembaran Negara Republik Indonesia Tahun 2016 Nomor 251, Tambahan Lembaran Negara Republik Indonesia Nomor 5952);

Undang-Undang Nomor 21 Tahun 2011 tentang Otoritas Jasa Keuangan (Lembaran Negara Republik Indonesia Tahun 2011 Nomor 111, Tambahan Lembaran Negara Republik Indonesia Nomor 5253);

Peraturan Bank Indonesia No 19/12/PBI/2017 tentang Penyelenggaraan Teknologi Finansial (Lembaran Negara Republik Indonesia Tahun 2017 No. 245, Tambahan Lembaran Negara Republik Indonesia Nomor 6142)

Peraturan Anggota Dewan Gubernur No 19 / 14 / PADG / 2017 tentang Ruang Uji Coba Terbatas / Regulatory Sandbox

Peraturan Otoritas Jasa Keuangan No. 13/POJK.02/2018 tentang Inovasi Keuangan Digital di Sektor Jasa Keuangan (Lembaran Negara Republik Indonesia Tahun 2018 Nomor 135, Tambahan Lembaran Negara Republik Indonesia Nomor 6238)

\section{Artikel dari Internet}

https://www.bi.go.id/id/sistem-pembayaran/fintech/Contents/default.aspx diakses tanggal 11 Juni 2019

https://www.cnbcindonesia.com/fintech/20180110145800-37-1126/ini-dia-empat-jenis-fintech-di-indonesia diakses tanggal 11 Juni 2019 
https://ekonomi.kompas.com/read/2018/10/18/144300126/geliat-fintech-di-era-industri-40?page=all diakses tanggal 11 Juni 2019

https://finance.detik.com/moneter/d-4340505/ojk-ada-9-juta-transaksi-fintech-di-ri diakses tanggal 11 Juni 2019

https://finance.detik.com/fintech/d-4551789/baru-5-fintech-lending-kantongi-izin-ojk diakses tanggal 11 Juni 2019

https://tirto.id/mengenal-regulatory-sandbox-rahim-dari-kelahiran-para-fintech-cJpW diakses tanggal 11 Juni 2019 